\title{
PERAN BUDGET EMPHASIS DALAM MEMODERASI HUBUNGAN PARTISIPASI ANGGARAN TERHADAP SENJANGAN DAN KINERJA MANAJERIAL (Studi Pada 30 SKPD Kota Ternate)
}

\author{
Suleman H. A. Kahar \\ Asrudin Hormati \\ Universitas Khairun
}

\begin{abstract}
This study aims to empirically test the effect of budgetary participation on budgetary slack and managerial performance. The study aims to empirically examines whether budget emphasis moderates budget participation on budget slack and managerial performance of Municipality Government of Ternate. Using moderated regression analysis, this study found that, 1) budgetary participation negatively affect budgetary slack 2) budget participation influences managerial performance and 3) budget emphasis moderates the relationship between budget participation on budgetary slack and managerial performance. The theoretical implications of this study indicate that agency and contingency theory could be used as a complement to a more effective budget participation process by integrating the expected performance measurement framework.
\end{abstract}

Keywords: participatory budgeting, ethics optimism, budget emphasis, budget slack, and managerial performance

\section{PENDAHULUAN}

Anggaran sektor publik merupakan instrumen akuntabilitas atas pengelolaan dan pelaksanaan program-program dibiayai dengan uang publik. Anggaran dalam organisasi sektor publik merupakan tahapan yang cukup rumit, mengandung nuansa politik yang tinggi. Anggaran sektor publik terkait dalam proses penentuan jumlah alokasi dana untuk tiap-tiap program, aktivitas dalam satuan moneter. Tahapan anggaran menjadi sangat penting karena anggaran yang tidak efektif dan tidak berorientasi pada kinerja akan menggagalkan perencanaan saat telah disusun (Mardiasmo 2005).
Anggaran melibatkan hubungan antar manusia, maka terdapat perilaku-perilaku manusia yang mungkin timbul sebagai akibat dari anggaran, baik yang bersifat perilaku positif maupun perilaku yang negatif. Perilaku yang positif dapat berupa peningkatan kinerja manajer karena termotivasi oleh anggaran yang digunakan sebagai dasar penilaian kinerja mereka. Perilaku negatif yang mungkin timbul adalah munculnya anggapan bahwa anggaran sering kali dipandang sebagai alat tekanan manajerial (Siegel dan Marconi. 1989).

Penekanan anggaran merupakan variabel yang dapat menimbulkan senjangan 
anggaran dengan argumentasi untuk meningkatkan kompensasi. Budget emphasis adalah kondisi bilamana anggaran dijadikan faktor yang paling dominan dalam pengukuran kinerja bawahan pada suatu organisasi. Pengukuran kinerja berdasarkan anggaran yang telah disusun membuat bawahan akan berusaha memperoleh variance yang menguntungkan dengan menciptakan senjangan anggaran antara lain dengan merendahkan penghasilan dan meninggikan biaya pada saat penyusunan anggaran.

Anggaran digunakan sebagai pengukur kinerja bawahan dalam suatu organisasi, maka bawahan akan berusaha meningkatkan kinerjanya dengan dua kemungkinan. Pertama, meningkatkan performance sehingga realisasi anggarannya lebih tinggi daripada yang ditargetkan sebelumnya. Kedua, melonggarkan anggaran pada saat penyusunan anggaran tersebut. Dengan melonggarkan anggaran manajer pusat pertanggungjawaban dikatakan melakukan upaya senjangan anggaran. Jika penekanan anggaran naik maka menyebabkan kinerja manajerial naik, karena penilian kinerja berdasarkan target pencapaian anggaran sehingga jika makin tinggi penekanan anggaran akan mempengaruhi kinerja manajerial. Penekanan anggaran rendah maka akan mengurangi kinerja manajerial, karena bawahan tidak terlalu dituntut dengan target anggaran yang sulit dicapai.

Beberapa peneliti akuntansi menemukan bahwa tingkat senjangan anggaran dipengaruhi oleh beberapa faktor, termasuk besarnya peran atau partisipasi bawahan di dalam penyusunan anggaran. Hasil penelitian-penelitian sebelumnya, yang menguji hubungan antara partisipasi bawahan dengan senjangan anggaran menunjukkan hasil yang tidak konsisten. Penelitian yang dilakukan Kren (2003), Maiga (2005), Maiga dan Jacobs (2008), Kren dan Maiga (2007) partisipasi dalam anggaran mengurangi jumlah senjangan anggaran. Sedangkan Basri (2010) Djasuli dan Fadila (2011), serta Jaya dan Rahardjo (2013). Collins, (1978), dan Vemy et al. (2011) dalam penelitiannya membuat kesimpulan bahwa partisipasi anggaran dengan senjangan anggaran mempunyai hubungan yang tidak signifikan. Dunk dan Nouri (1998) menemukan interaksi partisipasi anggaran negatif signifikan terhadap kinerja, Ramdeen, et al (2007) menemukan interaksi partisipasi anggaran dan budget emphasisnegatif signifikan terhadap senjangan anggaran, Davila dan Wouters, (2005) menemukan dalam penelitian mereka budget emphasis berpengaruh positif terhadap senjangan anggaran dan kinerja. Tristianto(2014) menemukan variabel tekanan 
anggaran memoderasi partisipasi anggaran senjangan anggaran tetapi nilai koefisien negatif. Erina dan Suartana, (2016), menyimpulkan dalam penelitian mereka bahwa variabel penekanan anggaran berpengaruh positif terhadap senjangan anggaran. Apriatini, et al (2014) menyimpulkan dalam penelitian mereka: (1) terdapat pengaruh positif signifikan antara partisipasi penyusunan anggaran terhadap senjangan anggaran, (2) terdapat pengaruh interaksi positif dan signifikan antara penekanan anggaran terhadap hubungan partisipasi anggaran dan senjangan anggaran, dan (3) terdapat pengaruh interaksi negatif dan signifikan antara komitmen organisasi terhadap hubungan partisipasi anggaran dan senjangan anggaran.

Irfan et al (2016) menemukan penekanan anggaran pengaruh negatif signifikan terhadap senjangan anggaran, hal ini menunjukkan bahwa asimetri informasi dan penekanan anggaran dapat menurunkan senjangan anggaran sehingga asimetri informasi dan penekanan anggaran bukan merupakan variabel pemoderesi.

Berbagai penelitian yang telah dilakukan untuk meneliti faktor-faktor yang mempengaruhi timbulnya senjangan sebagaimana diuraikan di atas memberikan hasil temuan yang tidak konsisten. Perbedaan hasil penelitian ini disebabkan oleh beragamnya variabel mediasi atau variabel moderasi yang dipilih dalam penelitian tersebut. Oleh karena itu penelitian ini mencoba kembali mengenai pengaruh partisipasi anggaran terhadap senjangan anggaran dengan budget emphasissebagai variabel moderasi. Govindarajan, (1988) mengatakan perlunya penelitian mengenai pendekatan kontijensi yang memungkinkan adanya variabel lain seperti informasi asimetri, komitmen organisasi, budget emphasis, yang bertindak sebagai moderating.

Hubungan yang dibentuk antara partisipasi anggaran dan senjangan anggaran telah menjadi topik utama, banyak diberbincangkan dalam literatur akademisi (Su dan Ni 2013). Namun bagaimana keterlibatan manajemen dalam pengaruh proses anggaran belum mendukung keberhasilan organisasi secara komprehnesif. Penelitian ini memperluas beberapa studi terdahulu mengenai partisipasi anggaran dan senjangan anggaran, tetapi menggunakan budget emphasis sebagai variabel moderasi. Penelitian ini membahas partisipasi anggaran dan senjangan anggaran di sektor publik.

Penelitian ini mengembangkan beberapa studi terdahulu. Masalah-masalah tersebut relevan untuk diteliti bagi pengembangan akuntansi manajemen khususnya anggaran 
dan senjangan anggaran. Bertitik tolak dari permasalahan yang ditemukan dalam penelitian sebelumnya, maka dirumuskan masalah dalam penelitian ini adalah: bagaimana peran budget emphasis memoderasi hubungan partisipasi anggaran, senjangan anggaran, dan kinerja manajerial.

Tujuan utama dari penelitian ini adalah membangun model teoritikal untuk menjelaskan peran budget emphasis dalam hubungan partisipasi anggaran, senjangan anggaran, dan kinerja manejerial.Hasil penelitian ini diharapkan memberikan kontribusi pengembangan teori, khususnya teori agensi, dan kontinjensi maupun bagi kepentingan praktek manajerial para praktisi dan akademisi sebagai pengembangan ilmu pengetahuan. Hasil penelitian ini diharapkan memberikan kontribusi terhadap pengembangan kajian dibidang akuntansi manajemen khususnya penerapan partisipasi anggaran dalam upaya meningkatkan efisiensi Satuan Kerja Perangkat Daerah.

\section{TELAAH TEORITIS DAN PENGEMBANGAN HIPOTESIS}

Pendekatan kontinjensi dalam perilaku organisasi adalah lingkungan yang berbeda menyebabkan adanya perilaku yang berbeda pula. Teori kontinjensi memotivasi adanya analisis situasi sebelum diambil tindakan dan menghilangkan perilaku yang biasa dilakukan berdasarkan asumsi tentang keprilakuan. Sehingga, teori kontinjensi dapat digunakan untuk semua pengetahuan yang mutakhir tentang organisasi dengan cara yang paling tepat, karena tindakan yang tepat bergantung pada variabel situasional. Govindarajan (1986) hubungan antara partisipasi anggaran terhadap senjangan anggaran dapat diselesaikan melalui pendekatan kontinjensi (contingency approach), yakni dengan memasukkan variabel-variabel lain yang dapat memoderasi hubungan antara partisipasi anggaran dan senjangan anggaran. Dalam penelitian ini faktor kontinjensi (contingency approach) adalah kepatuhan etika anggaran dan budget emphasis. Variabel-variabel tersebut yang akan memoderasi hubungan antara partisipasi anggaran dan senjangan anggaran.

Govindarajan (1986) menyatakan bahwa jika penelitian-penelitian sebelumnya mengindikasikan hasil yang saling bertentangan mengenai hubungan antara partisipasi anggaran dan kesenjangan anggaran, maka dapat digunakan pendekatan kontijensi sebagai prediktor adanya kesenjangan anggaran. Penelitian ini menggunakan faktor kontijensi untuk mengevaluasi keefektifan hubungan 
partisipasi anggaran pada kesenjangan anggaran.

Pendekatan kontijensi memungkinkan adanya variabel moderasi adalah variabel yang mepengaruhi hubungan partisipasi anggaran dan senjangan anggaran. Pendekatan kontijensi pada akuntansi manajemen didasari pada suatu anggapan bahwa sistem akuntansi secara universal selalu tepat untuk dapat digunakan pada seluruh organisasi dalam keadaan apapun, tetapi sistem akuntansi manajemen juga bergantung pada faktorfaktor situasional yang ada dalam organisasi tersebut.

\section{Senjangan Anggaran}

Senjangan anggaran digunakan oleh organisasi untuk pengawasan dan perencanaan kegiatan operasinya. Oleh karena itu, anggaran merupakan alat penting manajemen dalam meramalkan kondisi bisnis dimasa yang akan datang (Ramdeen et al., 2007). Terdapat dua alasan untuk ketidaktepatan dalam anggaran. Alasan pertama dapat disebabkan oleh kesalahan dan alasan yang kedua disebabkan oleh proses penyusunannya. Menurut Suartana (2010), senjangan anggaran adalah proses anggaran yang ditemukan adanya distorsi secara sengaja dengan menurunkan pendapatan yang dianggarkan dan meningkatkan biaya yang dianggarkan Menurut Falikhatun (2007), ada tiga fakor utama manajer melakukan senjangan anggaran (budgetary slack) adalah: (a) Orang-orang yang selalu percaya bahwa hasil pekerjaan mereka akan terlihat bagus di mata atasan jika mereka dapat mencapai anggarannya, (b) Senjangan anggaran selalu digunakan untuk mengatasi kondisi ketidakpastian. Jika tidak ada kejadian yang tidak terduga, yang terjadi manajer tersebut dapat melampaui atau mencapai anggarannya, dan (c) Rencana anggaran selalu dipotong dalam proses pengalokasian sumber daya. Penjelasan konsep senjangan anggaran dapat dimulai dari pendekatan kontijensi akan diadopsi untuk mengevaluasi partisipasi anggaran dan senjangan anggaran. Pendekatan kontijensi memungkinkan adanya variabelvariabel lain yang bertindak sebagai variabel moderasi yang memengaruhi hubungan antara partisipasi anggaran dan kesenjangan anggaran. Faktor kontijensi dalam penelitian ini adalah budget emphasis.

\section{Partisipasi Anggaran}

Salah satu faktor yang banyak diteliti dan dianggap memiliki pengaruh yang signifikan terhadap senjangan anggaran adalah partisipasi anggaran. Menurut Ikhsan dan Ishak (2005) partisipasi merupakan suatu proses pengambilan keputusan bersama oleh dua bagian atau lebih pihak dimana keputusan tersebut akan memiliki dampak masa depan 
terhadap mereka yang membuatnya. Manajer yang memiliki tingkat keterlibatan kerja (partisipasi) yang tinggi mengidentifikasi pekerjaan dan memelihara pekerjaan mereka, hal ini akan memilki kecenderungan yang lebih tinggi pula bagi manajer untuk menciptakan senjangan anggaran, yaitu untuk melindungi perkerjaan mereka dan untuk melindungi image mereka dalam jangka pendek. El-Masry (2009) menjelaskan bahwa manajemen harus berpartisipasi dalam peninjauan dan persetujuan anggaran, dan persetujuan tidak hanya sebagai stempel.

Partisipasi anggaran, semua tingkatan organisasi harus dilibatkan dalam penyusunan anggaran karena manajer puncak biasanya kurang mengetahui kegiatan sehari hari pada tingkatan bawah. Namun, manajer puncak mempunyai perspektif atau pandangan yang lebih luas atas perusahaan secara keseluruhan yang sangat vital terhadap pembuatan kebijakan anggaran secara umum. Rukmana, (2013) menunjukkan bahwa partisipasi anggaran berpengaruh signifikan terhadap perilaku disfungsional yaitu senjangan anggaran. Adapun indikator-indikatornya adalah sebagai berikut: (1) Pengaruh terhadap penetapan anggaran, (2) Seringnya atasan meminta pendapat atau usulan saat anggaran disusun, dan (3) Keputusan dalam penetapan anggaran.

\section{Kinerja Manajerial}

Kinerja manajerial adalah seberapa efektif dan efisien manajer telah bekerja untuk mencapai tujuan organisasi. Mahoney et al (1963) menyatakan bahwa kinerja berdasarkan pada kemampuan manajer dalam melaksanakan tugas manajerial.

Kinerja manajerial meliputi kemampuan manajer dalam perencanaan, investigasi, pengkoordinasian, evaluasi, pengawasan, pemilihan staff, negosiasi, dan perwakilan. Lebih jauh, Luthans dan Youssef (2007) menjelaskan bahwa para manajer yang dilibatkan dalam proses penyusunan anggaran dapat mengetahui seberapa besar kemampuan yang dimilikinya untuk mencapai target yang akan dicapai sehingga memunculkan keyakinan dalam diri manajer karena perasaan dihargai dan dipercaya.

\section{Budget Emphasis}

Dalam fungsinya sebagai alat perencanaan, anggaran dapat digunakan untuk merencanakan berbagai aktivitas suatu pusat petanggungjawaban agar dalam pelaksanaan aktivitasnya sesuai dengan apa yang telah digariskan. Anggaran dapat pula berfungsi sebagai alat pengendalian bilamana anggaran digunakan sebagai tolok ukur kinerja suatu pusat pertanggungjawaban. Jika dalam suatu organisasi anggaran merupakan faktor yang paling dominan dalam pengukuran kinerja 
bawahan, maka kondisi ini dinamakan tekanan anggaran atau budget emphasis. Ketika anggaran digunakan sebagai pengukur kinerja bawahan dalam suatu organisasi, maka bawahan akan berusaha meningkatkan kinerjanya dengan dua kemungkinan. Pertama, meningkatkan performance sehingga realisasi anggarannya lebih tinggi daripada yang ditargetkan sebelumnya. Kedua, melonggarkan anggaran pada saat penyusunan anggaran tersebut. Selain itu alasan lain manajer tingkat bawah berusaha melakukan senjangan adalah untuk meningkatkan kesempatan memperoleh penghasilan yang lebih apabila penghargaan yang diberikan ditandai dengan pencapaian anggaran, maka mereka akan cenderung membangun senjangan dalam anggarannya melalui proses partisipasi (Waller, 1988).

\section{Pengembangan Hipotesis}

Ramdeen et al. (2007) menyatakan bahwa tekanan anggaran dalam evaluasi kinerja dapat mendorong terciptanya senjangan anggaran. Alasan utama manajer tingkat bawah menciptakan senjangan dalam anggarannya tidak lain adalah untuk menciptakan kesempatan bagi mereka untuk meningkatkan imbalan yang akan mereka peroleh, jika manajer tingkat bawah merasa bahwa penghargaan yang mereka terima didasarkan atas pencapaian anggaran maka, mereka akan menciptakan senjangan anggaran ketika dalam proses partisipasi (Chow et al. 1988)

Penelitian yang dilakukan Sujana (2010) mengenai Pegaruh Partisipasi Anggaran Penekanan Anggaran Komitmen Organisasi Asimetri Informasi Dan Ketidakpastian Lingkungan Terhadap Budgetary Slack Pada Hotel-Hotel Berbintang Di Kota Denpasar, variabel penekanan anggaran tidak signifikan terhadap budgetary slack. Para manajer bawah, jika mereka menginginkan adanya rangsangan senjangan dalam anggaran mereka, maka mereka harus ikut serta dalam proses penyusunan anggaran (Lukka 1988).

Menurut Baiman (1991), bawahan yang berpartisipasi akan terdorong untuk membantu atasan dengan memberikan informasi yang dimilikinya sehingga anggaran yang disusun lebih akurat. Menurutnya, bawahan yang mempunyai informasi khusus tentang kondisi lokal akan melaporkan informasi tersebut kepada atasan. Individu yang memiliki komitmen tinggi akan mendahulukan kepentingan organisasi serta berusaha agar organisasi lebih produktif dan profitable.

Ramdeen et al. (2007) berasumsi bahwa manajer tingkat bawah berusaha melakukan senjangan dalam anggarannya jika 
asimetri informasi dan tekanan anggarannya tinggi. Akan tetapi, Chow et al. (1988) menerangkan bahwa jika tekanan anggaran tinggi dan asimetri informasi rendah, agen akan memiliki keinginan untuk mengembangkan senjangan, tetapi tidak memberikan jaminan keamanan terhadap anggarannya. Manajer tingkat bawah yang mengaharapkan mendapat keuntungan melalui senjangan anggaran mereka, maka mereka harus meningkatkan partisipasinya dalam proses penyusunan anggaran (Lukka 1988). Jika partisipasi rendah, kesempatan bagi manajer bawah untuk menciptakan senjangan dalam anggarannya sangat kecil dengan mengabaikan penyajian kepatuhan etika anggaran dan budget emphasis. Berdasarkan pengertian hipotesis dan hubungan dengan rumusan masalah serta uraian di atas, maka peneliti merumuskan hipotesis sebagai berikut:

$\mathrm{H}_{1}$ : Partisipasi anggaran berpengaruh negatif terhadap senjangan anggaran.

$\mathrm{H}_{2}$ : Partisipasi anggaran berpengaruh terhadap kinerja Manejerial

$\mathrm{H}_{3}$ : Interaksi partisipasi anggaran dan budget emphasisterhadap senjangan anggaran

$\mathrm{H}_{4}$ : Interaksi partisipasi anggaran dan budget emphasis terhadap kinerja manejerial

\section{METODE PENELITIAN}

\section{Pengumpulan Data dan Penentuan Sampel}

Data dalam penelitian ini diperoleh dari data primer melalui metode survei. Pengambilan sampel dilakukan dengan metode purposive samplings. Berdasarkan data di Pemerintah Daerah Kota Ternate sebanyak 30 SKPD 180 pejabat setingkat kepala bagian/bidang/subdinas dan kepala subbagian/subbidang/seksidari SKDP pada Pemerintah Daerah Kota Ternate. Pemilihan dinas dan kantor dilakukan dengan alasan yaitu instansi tersebut merupakan satuan kerja pemerintah, yang berarti menyusun, menggunakan dan melaporkan realisasi anggaran atau sebagai pelaksana anggaran dari pemerintah daerah.

\section{Definisi Operasional dan Pengukuran}

\section{Variabel}

\section{Senjangan Anggaran}

Senjangan anggaran didefinisikan sebagai perbedaan antara jumlah anggaran yang diajukan bawahan dengan jumlah estimasi terbaik dari organisasi (El-Masry 2009). Sedangkan Young mendefinisikan senjangan anggaran sebagai suatu jumlah, menyatakan produktivitas lebih rendah ketika bawahan diberi kesempatan untuk memilih standar kerja mereka yang digunakan untuk menilai kinerja. Anggaran dikatakan mengandung senjangan apabila 
bawahan menyusun target anggaran lebih rendah dari target peramalan terbaik masa depan sehingga target anggaran lebih mudah dicapai (Lukka 1988).

\section{Kinerja Manajerial}

Kinerja manajerial merupakan hasil upaya yang dilakukan manajer dalam melakukan tugas dan fungsinya dalam organisasi. Kinerja manajerial diukur dengan menggunakan instrumen daftar pertanyaan yang dikembangkan oleh Mahoney et al. (1965). Daftar pertanyaan tersebut terdiri dari delapan item pertanyaan digunakan untuk mengevaluasi kinerja responden. Alternatif jawaban atas daftar pertanyaan tersebut menggunakan skala Likert dengan rentang nilai satu (terendah) sampai dengan tujuh (tertinggi).

Kinerja manajerial dalam penelitian ini diukur dengan delapan dimensi kinerja yaitu: perencanaan, investigasi, pengkoordinasian, evaluasi, pengawasan, pengaturan staf, negosiasi, dan perwakilan/representasi.

\section{Partisipasi Anggaran}

Partisipasi anggaran adalah tingkat keterlibatan dan pengaruh para individu dalam proses penyusunan anggaran (Brownell 1982). Untuk mengukur variabel ini, peneliti menggunakan instrumen terdiri dari 6 item pertanyaan dikembangkan oleh (Milani 1975).
Ukuran partisipasi anggaran didasarkan pada tanggapan subyek terhadap serangkaian item menggunakan skala tujuh poin, dimulai dari: 1 (partisipasi yang rendah) sampai 7 (partisipasi yang tinggi).

Instrumen ini pernah digunakan oleh Chong (2002) melaporkan bahwa composite reliability instrumen ini 0,74 . Semakin besar jumlah skor diperoleh menunjukkan semakin tinggi keterlibatan individu dalam partisipasi anggaran. Sebaliknya semakin kecil jumlah skor yang diperoleh menunjukkan semakin rendah keterlibatan individu dalam partisipasi anggaran.

\section{Budget Emphasis}

Budget Emphasis adalah penggunaan anggaran sebagai satu-satunya pengukuran kinerja para manajemen perbankan. Variabel ini diukur dengan instrumen Hoopwood (1972) yang terdiri dari 7 item, setiap item pertanyaan yang digunakan dengan menggunakan skala likert 1 sampai 7 poin. Jawaban dari responden digunakan untuk menentukan tingkat budget emphasis. Tingkat budget emphasis yang rendah untuk skala rendah dan sebaliknya tingkat budget emphasis lebih tinggi.

\section{Teknik Analisis Data}

Untuk menguji hipotesis 1 dan 2 digunakan regresi sederhana. Dengan bentuk 
interaksi secara keseluruhan. Hipotesis 3 dan 4 diuji dengan regresi berganda dengan pendekatan uji interaksi. Model yang digunakan dalam penelitian ini disajikan dalam persamaan sebagai berikut:

Model persamaan regresi linear berganda untuk hipotesis pertama:

$$
\mathrm{Y}=\beta_{0}+\beta \mathrm{X}+\mathrm{e}(\text { hipotesis } 1)
$$

Dimana :

$\mathrm{Y}=$ Senjangan anggaran

$$
\mathrm{Y}=\beta_{0}+\beta \mathrm{X}+\mathrm{e}(\text { hipotesis } 2)
$$

Dimana :

$\mathrm{Y}=$ Kinerja manajerial

Model persamaan MRA untuk hipotesis ketiga:

$$
\mathrm{Y}=\beta_{0}+\beta 3 \mathrm{X}_{1}+\beta 3 \mathrm{Z}+\mathrm{PA} * \mathrm{Z} \text { e }
$$

Dimana :

$\mathrm{Y}=$ senjangan anggaran

$\mathrm{X}=$ Partispasi anggaran
$\mathrm{Z}=$ Interaksi PA dan BE

Model persamaan MRA untuk hipotesis keempat:

$$
\mathrm{Y}=\beta_{0}+\beta_{4} \mathrm{X}_{1} \beta \mathrm{Z} \mathrm{PA} * \mathrm{Z}+\mathrm{e}
$$

Dimana :

$\mathrm{Y}=$ Kinerja manajerial

$\mathrm{X}=$ Partispasi anggaran

$\mathrm{Z}=$ Interaksi PA dan BE

\section{Statistik Deskriptif}

Statistik deskriptif ini dimaksudkan untuk menggambarkan variabel-variabel yang digunakan dalam penelitian yaitu variabel partisipasi, senjangan anggaran, kinerja manajerial, dan budget emphasis. Berdasarkan hasil kuesioner yang diterima, tabel di bawah ini memperlihatkan kisaran teoritis dan aktual, mean, median, standar deviasi dari variabel penelitian dengan hasil sebagai berikut.

\section{Tabel 1}

Statistik Deskriptif Variabel Penelitian

\begin{tabular}{lccccc}
\hline \multicolumn{1}{c}{ Variabel } & N & Minimum & Maksimum & Mean & $\begin{array}{c}\text { Standar } \\
\text { Deviasi }\end{array}$ \\
\hline Senjangan anggaran & 145 & 19,00 & 61,00 & 44,0350 & 7,23101 \\
Kinerja manajerial & 145 & 6,00 & 42,00 & 29,5664 & 7,64306 \\
Partisipasi anggaran & 145 & 18,00 & 56,00 & 47,6923 & 6,80848 \\
Budget emphasis & 145 & 6,00 & 42,00 & 30,8671 & 6,74927 \\
\hline
\end{tabular}

Sumber: Data primer diolah, 2017

Berdasarkan tabel 1 dapat diketahui nilai terendah pada partisipasi anggaran adalah 18 dan nilai yang tertinggi adalah 56, sedangkan mean yang dihasilkan sebesar 47,6923 dan standar deviasi sebesar 6,80848, budget emphasis nilai terendah adalah 6 dan nilai yang tertinggi adalah 42, mean yang dihasilkan sebesar 30,8671 dan standar deviasi sebesar 6,74927. Untuk senjangan anggaran nilai terendah adalah 19 dan nilai yang tertinggi adalah 61, mean yang dihasilkan sebesar 44,0350 dan standar 
deviasi sebesar 7,23101. Nilai terendah kinerja manajerial adalah 6 dan nilai yang tertinggi adalah 42, mean yang dihasilkan sebesar 29,5664 dan standar deviasi sebesar 7,64306.

\section{Pengujian hipotesis}

Dalam analisis regresi, selain mengukur kekuatan hubungan antara dua variabel atau lebih, juga menunjukkan arah hubungan antara variabel dependen dan independen. Untuk menguji hipotesis pertama dan kedua menggunakan regresi sederhana, sedangkan hipotesis ketiga sampai dengan enam menggunakan moderated regression analysis berbeda dengan analisis sub kelompok, karena menggunakan pendekatan analitik yang mempertahankan integritas sampel dan memberikan dasar untuk mengontrol pengaruh variabel moderator.

\section{Hipotesis 1}

Terdapat enam hipotesis dalam penelitian ini. Hipotesis satu dan dua diuji dengan menggunakan analisis regresi linear. Sedangkan untuk pengujian hipotesis tiga sampai enam dilakukan dengan menggunakan analisis moderated regression analysis (MRA) (Hartamann dan Moers, 1999; Baron dan Kenny, (1986). Berdasarkan hasil pengujian hipotesis, dibawah ini disajikan tabel 5 dan 6 hasil output SPSS analisis regresi linear moderated regression analysis (MRA).

Pengujian hipotesis pertama, seperti terdapat pada tabel 4.6, menunjukkan Adjusted R-Square sebesar 0,349 atau 34,9\%. Hal ini berarti bahwa variasi perubahan senjangan anggaran hanya bisa dijelaskan oleh variabel independen (partisipasi anggaran) sebesar 34,9\% sedangkan sisanya $65,1 \%$ dijelaskan oleh variabel lain di luar model. Uji Anova atau F-test menghasilkan signifikansi p-value sebesar 0,000 atau $\mathrm{p}<0,05$. Hal ini berarti model regresi dapat digunakan untuk memprediksi variabel dependen (senjangan anggaran) dengan prediktornya variabel independen (partisipasi anggaran).

Pengujian selanjutnya menunjukkan nilai koefisien partisipasi anggaran sebesar negatif 0,378 dengan tingkat signifikansi $\mathrm{p}$ value sebesar 0,000 atau $p<0,05$. Hasil ini menunjukkan partisipasi anggaran berpengaruh negatif signifikan terhadap senjangan anggaran instansi pemerintah daerah kota Ternate. Hasil penelitian relevansi dengan teori keagenan telah digunakan untuk menjelaskan partisipasi anggaran. Teori keagenan menjelaskan bahwa, hasil yang diharapkan atasan dapat ditingkatkan dengan akses informasi terhadap bawahan sebelum proses persiapan anggaran. Melalui partisipasi 
dalam proses persiapan anggaran, atasan akan memperoleh kesempatan mendapatkan informasi dari bawahan yang dapat dikomunikasikan dan lebih akurat berupa lokal informasi yang nantinya akan digunakan sebagai standar yang dapat memberikan keuntungan dalam pengukuran kinerjanya
nanti.Temuan ini mendukung hasil Dunk (1993), Merchant, (1985), Kahar dkk., (2017), dan Hormati dkk., (2017) menyimpulkan bahwa partisipasi anggaran berpengaruh negatif terhadap senjangan anggaran.

Tabel 5

Hasil Uji Hipotesis 1 dan 2

\begin{tabular}{lcccccc}
\hline \multirow{2}{*}{ Variabel } & \multicolumn{2}{c}{ Model (1) Senjangan Anggaran } & \multicolumn{3}{c}{ Model(2) Kinerja manajerial } \\
\cline { 2 - 6 } & $\begin{array}{c}\text { Standardized } \\
\text { coefficient }\end{array}$ & T-value & $\begin{array}{c}\text { p- } \\
\text { value }\end{array}$ & $\begin{array}{c}\text { Standardized } \\
\text { coefficient }\end{array}$ & $\begin{array}{c}\text { T- } \\
\text { value }\end{array}$ & p-value \\
\hline $\mathrm{BP}$ & $-0,378$ & $-8,837$ & 0,000 & 0,353 & 3,573 & 0,000 \\
$\mathrm{R}$ & 0,595 & & & 0,286 & & \\
$\mathrm{R}^{2}$ & 0,354 & & 0,082 & & \\
Adjusted R & 0,349 & & 0,076 & & \\
F (p-value) & $78,271(0,000)$ & & $12,765(0,000)$ & \\
Sumber: Data primer diolah 2017 & & & & \\
\hline
\end{tabular}

Sumber: Data primer diolah, 2017

\section{Hipotesis 2}

Pengujian hipotesis 2 seperti terdapat pada tabel 5 menunjukkan Adjusted RSquare sebesar 0,076. Hal ini berarti bahwa variasi perubahan kinerja manejerial hanya bisa dijelaskan oleh variabel independen partisipasi anggaran sebesar $0,076 \%$ sedangkan sisanya 92,4\% dijelaskan oleh variabel lain di luar model. Uji Anova atau F-test menghasilkan signifikansi $\mathrm{p}$ value sebesar 0,000 atau $\mathrm{p}<0,05$. Hal ini berarti model regresi dapat digunakan untuk memprediksi variabel dependen (kinerja manajerial) dengan prediktornya variabel independen (partisipasi anggaran signifikan).
Hasil penelitian ini menunjukkan bahwa keterlibatan manajer dalam penetapan sasaran dapat memperbaiki kinerja. Satu studi menemukan bahwa masalah yang penting adalah menetapkan sasaran, bagaimanapun carapenetapannya. Dan sasaran tersebut akan lebih mudah dicapai jika anggota organisasi memahami sasaran yangdituju.Anggaran partisipatif merupakan pendekatan manajerial yang dianggap berpengaruh pada peningkatan efektifitas organisasional melalui peningkatan kinerja manajerial. Partisipasi anggaran dapat membantu manajer untuk lebih efektif dan efisien dalam pencapaian tujuan organisasi. Proses penyusunan anggaran partisipatif 
dapat meningkatkan kerjasama untuk pencapaian tujuan anggaran sehingga diharapkan dapat mudah dalam mencapai tujuan organisasi. Temuan ini mendukung hasil, Nouri dan Parker menyimpulkan bahwa partisipasi anggaran berpengaruh positif terhadap kinerja manajerial.

Tabel 6

Hasil Uji Hipotesis 3 dan 4

\begin{tabular}{lcccccc}
\hline \multirow{2}{*}{ Varabel } & \multicolumn{3}{l}{ Model (3) Senjangan Anggaran } & \multicolumn{3}{c}{ Model (4) Kinerja Manajerial } \\
\cline { 2 - 7 } & $\begin{array}{c}\text { Standardized } \\
\text { coefficient }\end{array}$ & $\begin{array}{c}\text { T- } \\
\text { value }\end{array}$ & $\begin{array}{c}\text { p- } \\
\text { value }\end{array}$ & $\begin{array}{c}\text { Standardized } \\
\text { coefficient }\end{array}$ & $\begin{array}{c}\text { T- } \\
\text { value }\end{array}$ & $\begin{array}{c}\text { p- } \\
\text { value }\end{array}$ \\
\hline $\mathrm{BP}$ & 0,225 & 9,046 & 0,032 & 0,581 & 16,136 & 0,001 \\
$\mathrm{BE}$ & 0,717 & 14,343 & 0,001 & 0,612 & 2,207 & 0,029 \\
$\mathrm{BP}^{*} \mathrm{BE}$ & 0,199 & 5,375 & 0,006 & $-0,680$ & 7,023 & 0,003 \\
$\mathrm{R}^{2}$ & 0374 & & & 0,144 & & \\
Adjusted R & 0,360 & & & 0,126 & & \\
F (p-value) & 12,238 & & $7,906(0,000)$ & & \\
& $(0,000)$ & & & & \\
\hline
\end{tabular}

Sumber: Data primer diolah, 2017

\section{Hipotesis 3}

Untuk kepentingan uji interaksi, perlu disiapkan data interaksi antara variabel partisipasi anggaran dengan masing-masing variabel moderating. Interaksi variabel partisipasi anggaran dengan variabel budget emphasis dinyatakan dalam moderat 1 . dilakukan dengan menggunakan analisis moderated regression analysis (MRA) (Venkratraman, 1989; Venkatesh dan Blaskovich, 2012). Dari output yang ditampilkan pada tabel 6 di atas, pada pengujian hipotesis 3 diperoleh hasil bahwa budget emphasis merupakan sebagai pure moderator dalam hubungan antara partisipasi anggaran dan senjangan anggaran.
Tampilan output SPSS dari uji hipotesis 3 menghasilkan besarnya AjustedR-Square $=0,374$, hal ini berarti $37,4 \%$ variasi senjangan anggaran dapat dijelaskan oleh variasi variabel independen partisipasi anggaran, budget eemphasis. Selebihnya sebesar $37,4 \%$ dijelaskan oleh sebab-sebab lain diluar model. Uji signifikansi simultan mengasilkan nilai Fhitung sebesar 12,238 dengan tingkat signifikan 0,000 menunjukkan probablitas signifikansi lebih kecil dari 0.05, maka dapat dikatakan bahwa partisipasi anggaran, budget emphasis sebagai moderasi secara bersama-sama berpengaruh terhadap senjangan anggaran. Berdasarkan tabel 6 dapat diketahui bahwa terdapat pengaruh 
antara variabel budget emphasis dalam memoderasi partisipasi anggaran dan senjangan anggaran yang ditunjukkan dengan nilai t-hitung sebesar 5375 dengan signifikasi sebesar 0,006 yang lebih kecil dari $\alpha=0,05$. Hasil temuan ini konsisten dengan Ikhsan dan Ane (2007), interaksi partsipasi anggaran dan gaya kepemimpinan, Sardjito dan Muthaher (2007), interaksi partisipasi anggaran dan budaya organisasi, dan Apriantini dkk., (2014), menemukan terdapat interkasi penekanan anggaran terhadap hubungan partisipasi anggaran dan senjangan anggaran, penelitian ini menemukan bahwa variabel budget emphasis sebagai pure moderator. Pendekatan kontigensi atau pendekatan situasional merupakan suatu pandangan bahwa teknik manajemen yangpaling baik memberikan kontribusi untuk pencapaian sasaran organisasi mungkin bervariasi dalam situasi atau lingkungan yang berbeda.

\section{Hipotesis 4}

Untuk uji hipotesis 4 pada persamaan keempat, uji Anova atau F-test menghasilkan F-hitung sebesar 7,906 dengan tingkat signifikansi 0,000 pada persamaan 3 dan F-hitung sebesar 12,238 dengan derajat signifikansi 0,000 . Nilai signifikansi ini dibandingkan dengan probabilitas 5\%, maka dikatakan bahwa partisipasi anggaran, budget emphasis dan moderat 4 secara bersama-sama berpengaruh terhadap kinerja manajerial. Untuk menyimpulkan bahwa variabel budget emphasis sebagai variabel moderating perlu diperhatikan persamaan (1), (2) dan (3). Ketiga persamaan tersebut berbeda, yakni nilai koefisien $\beta \neq 0$. Hasil analisis pada tabel 5., hubungan antara partisipasi anggaran terhadap senjangan anggaran dengan budget emphasis bernilai koefisien negatif sebesar 0,680 dengan tingkat signifikan pada $p=0,003$ yang artinya budget emphasis mempunyai pengaruh moderating terhadap hubungan antara partsipasi anggaran dan kinerja manajerial. Dengan demikian hipotesis (4) yang menyatakan bahwa interkasi partisipasi anggaran dan budget emphasis berpengaruh signifikan terhadap hubungan antara partisipasi anggaran dan kinerja manajerial diterima. Hasil ini semakin memperkuat konsep dari teori kontinjensi sebagaimana yang dipaparkan di bagian sebelumnya.

\section{KESIMPULAN DAN IMPLIKASI}

\section{Kesimpulan}

Berdasarkan hasil analisis sebagaimana telah diuraikan sebelumnya maka dapat diambil kesimpulan sebagai berikut: (1). Partisipasi anggaran berpengaruh negatif signifikan terhadap senjangan anggaran pada Pemerintah Kota 
Ternate, (2). Partisipasi anggaran berpengaruh negatif signifikan terhadap kinerja manajerial pada Pemerintah Kota Ternate, (3). Budget emphasis memoderasi hubungan antara partisipasi anggaran terhadap Senjangan anggaran SKPD Pemerintah Kota Ternate, dan (4). Budget Emphasis juga memoderasi hubungan antara partisipasi anggaran terhadap kinerja manajerial pada SKPD Pemerintah Kota Ternate.

\section{Implikasi}

Pimpinan SKPD pada Pemerintah

Kota Ternate hendaknya dapat lebih meningkatkan partisipasi anggaran yaitu dengan cara meningkatkan keterlibatan seluruh lini pejabat struktural dalam proses penyusunan anggaran sehingga kinerja yang mereka hasilkan akan semakin baik. Adanya pengaruh budget emphasis atas peningkatan hubungan partisipasi anggaran dan senjangan anggaran serta kinerja manajerial pada Pemerintah Kota Ternate, sangatlah perlu bagi para pejabat struktural yang terlibat dalam proses penyusunan anggaran untuk menumbuhkan budget emphasis yang lebih agar senjangan anggaran dan kinerja manajerial yang dihasilkan menjadi lebih baik lagi

Salah satu upaya yang dapat dilakukan yaitu dengan cara menerapkan sistem reward dan punishment secara nyata, struktur desentralisasi akan menempatkan para pejabat struktural sesuai tugas pokok dan fungsi, sehingga wewenang dan tanggung jawab yang menjadi tugas mereka akan membuat kinerja pejabat struktural lebih baik.

\section{DAFTAR PUSTAKA}

Apriantini, N. K. E., I. M. P. Adiputra, dan E. Sujana. 2014. Pengaruh Partisipasi Anggaran Terhadap Senjangan Anggaran Dengan Penekanan Anggaran Dan Komitmen Organisasai Sebagai Variabel Moderating. e-Journal S1 Ak Universitas Pendidikan Ganesha 2 (1):1-11.

Baiman, S. 1991. The Value Of Private PreDecision Information In A PrincipalAgent. The Accounting Review 66 (4):747-766.

Baron, R. M. dan D.A. Kenny, D. A. 1986. The Moderator-Mediator Variable. Distinction in Social Psychological Research: Conceptual, Strategic, and. Statistical Considerations. Journal of Personality and Social Psychology. 51(6), 1173-1182

Basri, Y. M. (2010). Pengaruh Penganggaran Partisipasi dan Job Relevan Information Terhadap Budget Slack Pemerintah Provinsi Riau. Jurnal Ilmu Administrasi Negara, 10(1), 69-77

Brownell, P. 1982. A Field Study Examination Of Budgetary Participation And Locus Of Control The Accounting Review 57 (4):766-777.

Chong, V.K., dan K.M. Chong. 2002. Budget goal commitment and informational 
effects of budget participation on performance. Accounting and Business Research, 37(1): 65-86

Chow, C. W., J. C. Cooper, dan W. S. Waller. 1988. Parcipative Budgeting: Effects Of A Testing-Inducing Pay Shema And Information Asymmetry On Slack And Performance. The Accounting Review 18 (1):111-122.

Collins, F. 1978. The Interaction Of Budget Characteristics And Personality Variables With Budgetary Response Attitudes. The Accounting Review 53 (2):324-335.

Davila, T., dan M. Wouters. 2005. Managing budget emphasis through the explicit design of conditional budgetary slack. Accounting, Organizations and Societym 30 (7-8):587-608

Djasuli, M., dan Fadila, N. I. (2011). Efek Interaksi Informasi Asimetri Budaya Organisasi Group Cohesieness Dan Motivasi Dalam Hubungan Kausal Antara Budgeting Participation Dan Budgetary Slack. Proceeding Pesat, 4, 1-6.

Dunk, A. S. 1993. The Effect Of Budget Emphasis And Information Asymmetry On The Relation Between Budgetary Participation And Slack. The Accounting Review 68 (2):400-410.

Dunk, dan Nouri, H. (1998). Antecedents Of Budgetary Slack: A Literature Review And Synthesis. Journal of Accounting Literature 17, 72-96.

El-Masry, E.-H. E. 2009. Training Accounting Students On The Prevention Of Budgetary Slack And Its Impact On Feedback-Seeking Behaviour. Training
\& Management Development Methods 23 (2):331-343.

Falikhatun. 2007. Interaksi Informasi Asimetri, Budaya Organisasi, Dan Group Cohesiveness Dalam Hubungan Antara Partisipasi Penganggaran Dan Budgetary Slack (Studi Kasus pada Rumah Sakit Umum Daerah Se Jawa Tengah). Paper read at Simposium Nasional Akuntansi X, at Makassar.

Govindarajan, V. 1986. Impact Of Participation In The Budgetary Process On Managerial Attitudes And Performance: Universalistic And Contingency Perspectives. Decision Science 17:496-516.

Govindarajan, V. 1988. A Contingency Approach To Strategy Implementation At The Business-Uunit Level: Integrating Administrative Mechanisms With Strategy. Academy of Management Journal 31 (4):828-853.

Hartmann, F.G.H., dan F. Moers. 1999. Testing contingency hypotheses in budgetary research: an evaluation of the use of moderated regression analysis. Accounting, Organizations and Society, 24(4): 291-315

Hoopwood, A. G. 1972. An Empirical Study Of The Role Of Accounting Data In Performance Evaluation. Journal of Accounting Research 10:156-182.

Hormati, A., R. Laduna, S. A. Mahdi, dan S. H. A. Kahar. 2017. The Effect ff Budgetary Participation on Budgetary Slack Using Budgetary Ethical Compliance As The Mediating And Moderating Variable International Journal of Civil Engineering and Technology 8 (8):1081-1092. 
Ikhsan, A., dan M. Ishak. 2008.Akuntansi Keperilakuan. Salemba Empat: Jakarta.

Ikhsan, A., dan L. Ane. 2007. Pengaruh Partisipasi Anggaran Terhadap Senjangan Anggaran Dengan Menggunakan Lima Variabel Pemoderasi. In Simposium Nasional Akuntansi Makassar, 1-27.

Irfan, M., B. Santoso, dan L. Effendi. 2016. Pengaruh Partisipasi Anggaran terhadap Senjangan Anggaran dengan Asimetri Informasi, Penekanan Anggaran dan Komitmen Organisasional sebagai Variabel Pemoderasi. Jurnal Akuntansi dan Investasi 17 (2):158-175.

Jaya, M. F. D., dan T. Rahardjo. 2013. The Effects Of Budget Participation, Asymmetric Information, Budget Emphasis, And Organizational Commitment On Budgetary Slack In Pemerintah Kota Pasuruan. 1-29.

Kren, L. 2003. Effects Of Uncertainty, Participation, And Control System Monitoring On The Propensity To Create Budget Slack And Actual Budget Slack Created. Advances in Management Accounting 11:143-167.

Kren, L., dan A. S. Maiga. 2007. The Itervening Effect Of Information Asymmetry On BudgetT Paryicipation And Segment Slack. Advances in Management Accounting 16:141-157.

Lukka, K. 1988. Budgetary Biasing In Organizations: Theoretical Framework And Empirical Evidence. Accounting Organizations and Society 13:281-301.

Luthans, F., dan C. M. Youssef. 2007. Emerging Positive Organizational Behavior. Published in Journal of Management 33 (3):321-349.
Mahoney, T. A., T. H. Jerdee, dan S. J. Carroll. 1965. The Job(s) Of Management. Harvard Business Review, 35:89-94.

Maiga, A. S. 2005. The Effect Of Manager's Moral Equity On The Relationship Between Budget Participation And Propensity To Create Slack: A Research Note. Advances in Accounting Behavioral Research 8:139-165.

Maiga, A. S., dan F. A. Jacobs. 2008. The Moderating Effect Of Manager's Ethical Judgment On The Relationship Between Budget Participation And Budget Slack. Advances in Accounting 23:113-145.

Mardiasmo. 2005.Akuntansi Sektor Publik. Yogyakarta: Andi.

Milani, K. 1975. The Relationship Of Participation In Budget-Setting To Industrial Sopervisor Performance And Attitudes: A Field Study The Accounting Review:274-284.

Nouri, H., dan R. J. Parker. 1998. The Relationship Between Budget Participation and Job Performance: The Roles Of Budget Adequacy and Organizational Commitment. Accounting Orgnnizatiom and Societ 23 (6):467-483.

Ramdeen, C., J. Santos, dan H. K. Chatfield. 2007. An Examination Of Impact Of Budgetary Participation Budget Emphasis And Information Asymmetry On Budgetary Slack In The Hotel Industry. Harrah College of Hotel Administration:1-15.

Sardjito, B., dan O. Muthaher. 2007. Pengaruh Partisipasi Penyusunan Anggaran Terhadap Kinerja Aparat Pemerintah Daerah: Budaya Organisasi dan Komitmen Organisasi Sebagai 
Variabel Moderating. In Simposium Nasional Akuntansi. Makassar, 1-24.

Siegel, G., dan H. R. Marconi. 1989.Behavioral Accounting. Cincinnati Ohio: South-Western Publishing Co.

Sujana, I. K. 2010. Pengaruh Partisipasi Penganggaran Penekanan Anggaran Komitmen Organisasi Asimetri Informasi Dan Ketidakpastian Lingkungan Terhadap Budget Salck Pada Hotel-Hotel Berbintang Di Kota Denpasar. Jurnal Ilmiah Akuntansi dan Bisnis 5 (2): 1-26.

Su, C.-C., dan F.-Y. Ni. 2013. Budgetary Participation And Slack On The Theory Of Planned Behavior. The International Journal of Organizational Innovation 5 (4):91-99.

Suartana, I. W. 2010.Akuntansi Keperilakuan Teori Dan Implementasi. Yogyakarta: C.V Andi Offset.

Tristianto, A. 2014. Pengaruh Partisipasi Anggaran Terhadap Budget Slack Dengan Asimetri Iformasi Dan Tekanan Anggaran sebagai Pemodarsi. Jurnal Ilmu \& Riset Akuntansi 3 (5):1-15.

Vemy, A., Pagalung, G., dan Syarifuddin. (2011). The Influence of the Interaction between Organisation Commitment Budget Participation, and Work Involvement on the Consistency of Budget Use in the Health Office of West Sulawesi Province, 1-15.

Venkatraman, N. 1989. The concept of fit in strategy research: toward verbal and statistcial correspondence. Academy of Management Review 14(3): 423-444

Venkatesh, R. dan J. Blaskovich (2012). The Mediating Effect of Psychological Capital on the Budget Participation-Job Performance Relationship. Journal of
Management Accounting Research. 24(1), 159-175

Waller, W. S. 1988. Slack In Participative Budgeting: The Joint Effects O F A Truth-Inducing Pay Scheme And Risk Preferences. Accounting, Organization, and Society 3 (1):87-98.

Young, S. M. 1985. Participative Budgeting: The Effects Of Risk Aversion And Asymmetric Information On Budgetary Slack. Journal of Accounting Research 23 (2):829-842. 